Strains 57 and 13 can be transduced to streptomycin rosistance by phages $12 / 57$ and $34 / 13$ propagated on streptomycin-resistant mutants of 57 and 13 respectivelys. Lysogenic transductants possess all the properties of strains lysogenized with non-transducing phage.

Differences in properties of strains 57 and $57(12 / 57)$ and strains 13 and $13(34 / 13)$ are attributed to the presence of converting prophages $12 / 57$ and 34/13. Conversion is in respect of phage-adsorbing capacity and possibly other antigenic changes as well.

Phages $12 / 57$ and $34 / 13$ are thus competent in transducing and convorting systems. A similar position obtains with Salmonella phage P22. This phage has been extensively used in transduction exper. iments and can produce lysogenic conversion". A possible difference is that this phage is capable of producing conversion in the vegetative state (phage conversion). No attempt has yet been made to investigate the latter possibility for the Proteus phages mentioned.

This work was aided by grants from the South African Council for Scientific and Industrial Research.

\section{J. N. Coetzer}

Department of Microbiology,

University of Pretoria, P.O. Box 2034,

\section{Pretoria.}

2 Bertani, G., J. Bact., 87, 696 (1954). Burnet, F. M., and Lush, D., Atrstral. J. Exp. Biol. Med. Sci., 14,
27 (1938).

- Uetske, H., Luria, S. K., and Burrous, J. W., Virology, 5, 68 (1958).

- Stocker, B. A. D., J. Gen. Microbiol, 18, 9 (1958).

- Lederberg, J., J. Cell. Comp. Phyriol., 45, Suppl. 2, 75 (1955).

- Coetzee, J. N., and Sacks, T. G., Nature, 185, 869 (1960).

- Belyavin, G., J. Gen. Microbiol., 5, 197 (1951).

- Lederberg, E. M., and Lederberg, J., Genetice, 88, 51 (1953).

- Coetzee, J. N., S. Afr. J. Lab. Clin. Med., 4, 147 (1958).

10 Kippax, P. W., J. Clin. Path.. 10, 211 (1957).

\section{Elimination of Transmissible Drug-resistance by Treatment with Acriflavin}

The first isolation of multiple resistant Shigella was reported by Kitamoto ${ }^{1}$. This was resistant to four drugs $\left(r_{\star}\right)$ : streptomycin, tetracycline, chloramphenicol and sulphanilamide. $\boldsymbol{E}$. coli $r_{\text {, was }}$ isolated in the epidomic of Sh. flexneri $3 a r_{4}$ (refs. 2 and 3). Sh. flexneri $2 a r_{3}$ and $E$. coli $r_{8}$ wore also isolated in snother epidemic, which wore resistant to streptomycin, chloramphenicol and sulphanilamide*. Citrobacter $r_{4}$ and $E$. coli $r_{\text {, were isolated from a }}$ dysenteric patient after treatment with chloramphenicols.

From the epidemiological investigation of the multiple resistant Escherichia in the freces of human beings', we have loarned more about the multiple resistant Shigella and the general phenomena among Enterobacteriscese.

Ochiai? and Akibs ${ }^{8}$ reported that the multiple resistance was transmitted botwoen Shigella and $E$. coli following mixed cultivation. This transmission is not mediated by transduction, transformation or filtrable agent, but by cell-to-cell contact, 10 without regard to the polarity of $F$ factor ${ }^{11}$. It has also been shown that the multiple rosistance is transmitted between overy genera of Enterobacteria. $\operatorname{ces}^{12}$, whereas perhaps only $3 \cdot-5$ per cent of the strains of Escherichia would have given positive results in bacterial recombination.
Artificial elimination of the transmissible drug. resistance by treatment with acriflavin was carried out by Hirots's mothod ${ }^{18}$.

The drug-resistant cells were inoculated into Difco brain-heart infusion broth containing sub. lethal concentrations of acriflavin $(20 \mu \mathrm{gm}$. $/ \mathrm{ml}$. for $E$. coli and $10 \mu \mathrm{gm} . / \mathrm{ml}$. for Shigella). After overnight incubstion at $37^{\circ} \mathrm{C}$, the cells were streaked on Drigalski's medium and the drug-resistance of each colony was tested. Heart infusion agar was used for assaying resistance to streptomycin, chloramphenicol and tetracycline. For assaying sulphanilamide resistance, semi-synthetic modium was used. It consists of 1 litre of medium $A$ (ref. 14) agsr enriched with $2.0 \mathrm{gm}$. cassmino-acid, $10 \mathrm{mgm}$. tryptophan, $2 \mathrm{mgm}$. nicotinic acid, $10 \mathrm{mgm}$. thiamin hydrochloride and $2 \mathrm{gm}$. glucose. The results are shown in Table 1.

Table 1. Freqcency of Elimination of DRUg-Rrsistance BY TREATHENT WITH ACRIPLAVIN

\begin{tabular}{|c|c|c|}
\hline Micro-onganisms & $\begin{array}{l}\text { With acriflavin } \\
\text { treatment }\end{array}$ & $\begin{array}{c}\text { Without acriflavin } \\
\text { treatment }\end{array}$ \\
\hline 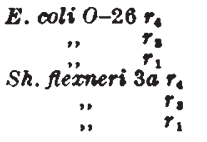 & $\begin{array}{c}5 / 579(0.9 \%) \\
15 / 547(2.9 \%) \\
0 / 579 \\
241 / 517(46.6 \%) \\
0 / 375 \\
201 / 583(36.2 \%)\end{array}$ & $\begin{array}{l}0 / 1,589 \\
0 / 881 \\
0 / 364 \\
0 / 1,198 \\
0 / 1,177 \\
0 / 1,116\end{array}$ \\
\hline
\end{tabular}

$T_{\text {. }}$ resistant to streptomycin, chloramphenicol, tetracycline and sulphanllamide; $r$, resistant to streptomy cin, tetracycline and sulph-

- Numerator, number of the drug-sensitive colonj; denominator, number of the total colonies tested.

The drug-resistance of both Escherichia and Shigella were eliminated from the drug-resistant cells after treatmont with acriflavin, and tho frequency of elimination of the drug-resistance was higher in Shigella than in Escherichia. This fact is in agreement with the finding that the loss of the drug-resistance with Shigella was more frequent than with Escherichia after 6 months storage in cooked meat media. It was also found that all markers for drug-resistance were lost by treatment with acriflavin and the colls became sensitive to all drugs. The drug-sensitive cells thus obtained were not able to transmit the drug-resistance by mixed cultivation with other drug-sensitivo cells.

\section{S. MrtsUHABHI \\ K. Harada \\ M. KAMEDA}

Department of Microbiology,

School of Medicine,

Gunms University, Mrebashi, Japan.

1 Kitamoto, O., et al., Jap. J. Infect. Dis., 80, 403 (1958).

Matsuyama, T., Harada, K., et al., Nihonijishimpo (Japan), No. $1795,22(1958)$.

Mitsuhashi, S., Harada, K., et al., J. Bact. (Japan), 15, 844 (1960).

4 Harada, K., Mitsuhashi, S., et al., Japan. J. Exp. Med. (in the press).

- Harada, K., Mitsuhashi, S., et al., J. Bact. (Japsn) (In the press).

- Mitauhashi, S., Harada, K., and Hashimoto, H., Med. and Biol., 65, $87(1960)$.

'Ochial, K., et al., Nihonijishimpo (Japan), No. 1861, 34 (1959).

- Akiba, T., ef al., Nihonijishimpo (Japan), No. 1866, 46 (1960).

- Harada, K., Mitsuhashi, S., et al., J. Bact. (Japan) (in the press).

so Mitsuhashi, S., Harada, K., and Hashlmoto, H., Jap. J. Exp. Med., $30,178(1960)$.

${ }^{11}$ Lederberg, J., Proc. U.S. Nat. Acad. Sci., 43, 1060 (1957).

12 Harads, K., Mitsuhashl, S., et al., Jap. J. Exp. Med. 30, 289 (1960).

13 Hirota, Y., Nature, 178, 42 (1956).

16 Davis, B. D., and Mingioli, B. S., J. Bact., 60, 17 (1950). 